\title{
Probiotics on performance, intestinal morphology and carcass characteristics of broiler chickens raised with lower or higher environmental challenge
}

\author{
Lilian F.A. de Souza ${ }^{a}$, Denise N. Araújo ${ }^{b}$, Lenita M. Stefania ${ }^{a}$ Ines C. Giomettia, \\ Valquíria C. Cruz-Polycarpo ${ }^{c}$, Gustavo Polycarpoc, Maria F. Burbarelli ${ }^{\mathrm{d}}$
}

\begin{abstract}
This study aimed to evaluate the effect of probiotics on performance, intestinal morphology and carcass characteristics of broiler chickens housed on lower or higher environmental challenge. Three hundred male Cobb chicks were distributed into four groups in completely randomised design with treatments arranged in a $2 \times 2$ factorial scheme to evaluate effects of two diets (with or without probiotics) and two environmental conditions (lower or higher challenge), totaling four treatments with five replications with 15 birds per box. Probiotics were added on diets and were composed of Lactobacillus acidophilus, Bacillus subtilis, Bifidobacterium bifidum and Enterococcus faecium. The environment with lower challenge was made up of new wood shavings used as litter, low bird density $\left(8 \mathrm{birds} / \mathrm{m}^{2}\right)$ and daily-cleaned bell drinkers. The environment with higher challenge was made up of re-used wood shavings used as litter (after three broods of broilers), bird density of $16 \mathrm{birds} / \mathrm{m}^{2}$ with bell drinkers cleaned every two days. No significant interaction between diet and environmental challenge was found for any of the variables evaluated. Performance, slaughterhouse variables and chemical carcass composition were not affected by the use of probiotics. Chicks receiving diets without probiotics had lower intestinal crypt depth ( 267.1 vs. $316.6 \mu \mathrm{m}, P=0.0068)$. Birds raised in the environment with higher challenge decreased feed intake (4,660 vs $5,020 \mathrm{~g}, P=0.0422)$, weight gain $(2,610 \mathrm{vs} 2,810 \mathrm{~g}, P=0.0054)$, drumstick and thigh yield ( 21.98 vs $24.14 \%, P=0.0354)$, and increased crypt depth ( $325.2 \mathrm{vs} 258.5 \mu \mathrm{m} P=0.0009)$. In conclusion, the probiotic does not promote satisfactory improvements, regardless of the environmental challenge.

Key words: additives, intestinal health, poultry, sanitary challenge.
\end{abstract}

\section{INTRODUCTION}

Growth promoters are antibiotics that have been used to improve the performance of broiler chickens since its discovery near 1950. However, since 2006 the European Union banned the use of antibiotics as growth promoters in animal feed, and the use of alternative additives (non-antibiotics) have been increased (Huyghebaert et al 2011).

According to Fuller (1989), probiotics are single or mixed cultures of live microorganisms which beneficially affect the host by improving the balance of their intestinal flora. The use of probiotics stimulates the proliferation of beneficial microorganisms, rather than the proliferation of potentially pathogenic bacteria (Puupponen-Pimiä et al 2002). The evaluation of the effect of probiotics on performance, development of the intestinal mucosa and carcass characteristics resulted on divergent outcomes. Comparing probiotics to control group, positive results were obtained on the performance (Ramos et al 2014, Marubashi et al 2012, Sen et al 2012, Patel et al 2015), on the development of intestinal mucosa of broilers (Sen et al 2012, Fallah et al 2013) and on the carcass (Boostani

\footnotetext{
Accepted: 29.08.2017.

aUniversity of Western São Paulo, São Paulo, Brazil.

bUniversity of West Santa Catarina, Florianópolis, Brazil.

${ }^{\mathrm{c} S a ̃ o ~ P a u l o ~ S t a t e ~ U n i v e r s i t y, ~ C o l l e g e ~ o f ~ A g r i c u l t u r a l ~ a n d ~ T e c h n o l o g i c a l ~}$ Sciences, São Paulo, Brazil.

${ }^{\mathrm{d} D e p a r t m e n t ~ o f ~ A n i m a l ~ N u t r i t i o n ~ a n d ~ P r o d u c t i o n, ~ U n i v e r s i t y ~ o f ~ S a ̃ o ~}$ Paulo, São Paulo, Brazil.

*Corresponding author: MF Burbarelli; Av. Duque de Caxias Norte, 225, Pirassununga, SP, 13635-900, Brazil; mfcb@usp.br
}

et al 2013). However, other results show no significant effect on performance (Souza et al 2011, Shargh et al 2012, Domingues et al 2014) and carcass yield (Souza et al 2011, Domingues et al 2014).

Studies have reported that when the animals are raised on a low pathogen environment, growth promoters show no effect on performance (Gunal et al 2006, Shargh et al 2012). In this sense, most experimental conditions do not expose the birds to pathogenic bacteria, making the environment a determining potential of probiotics efficiency, as well as the age of the birds, the route and the time of administration (Timmerman et al 2006).

On the other hand, common practice in the commercial poultry breeding such as high density and re-use of litter offer challenges and expose the animals to factors that result in stress and increased proliferation of pathogenic microorganisms. Raising broilers in high density aims to increase productivity and profitability in poultry. Thus, housing a larger number of birds per area results in increased production rate per working area despite lower individual productivity per birds. High densities result in changes indicative of stress parameters such as gait, feather and foot and hock burn scores (Ravindran et al 2006) and expression of genes encoding proteins related to stress (Beloor et al 2010) and modified intestinal microbiota (Guardia et al 2011). Still, the main arguments for re-using poultry litter are cost reduction, reduced withdraw period between flocks and minimised environmental impact (Mendes et al 2004). Baracho et al (2013) suggested that the creation of broiler chickens in poultry with re-used litter could result in stressful conditions, such as heat with increased temperature. According to Cressman et al (2010), 
litter conditions interfere with the intestinal microbiota of broilers. Still, studies report damage to the immune, respiratory and digestive system by re-using litter (Lee et al 2011, Malone, 2006, Costa et al 2000).

In the present study, the aim was to evaluate the effects of probiotics on performance, duodenal morphometry and carcass characteristics of broiler chickens exposed to lower or higher challenge conditions through different raising environments.

\section{MATERIAL AND METHODS}

All procedures were conducted in accordance with the Ethics Committee of Animal Use of University of Western São Paulo (UNOESTE), project protocol number: 192.

\section{EXPERIMENTAL BIRDS, DESIGN AND TREATMENTS}

Three hundred one-day-old male Cobb chicks were distributed in a completely randomised design as a $2 \times 2$ factorial scheme, composed of two diets (with or without probiotics) and two environmental conditions (lower or higher environmental challenge), totaling four treatments with five replications with 15 birds per pen. Water and mash feed were provided ad libitum. A 23-h lighting program was employed.

The diets of the starter phase (1 to $21 \mathrm{~d}$ ) and growth (22 to $42 \mathrm{~d}$ ) were isocaloric and isonitrogenous, formulated according to Rostagno et al (2005). The probiotics used was composed of Lactobacillus acidophilus $\left(1 \times 10^{9}\right.$ $\mathrm{cfu} / \mathrm{g})$, Bacillus subtilis $\left(2.8 \times 10^{9} \mathrm{cfu} / \mathrm{g}\right)$, Bifidobacterium bifidum $\left(2 \times 10^{9} \mathrm{cfu} / \mathrm{g}\right)$ and Enterococcus faecium $\left(2 \times 10^{9} \mathrm{cfu} / \mathrm{g}\right)$, which was added to the feed during the whole experimental period (table 1).

The environment with lower challenge was made up of new wood shavings used as litter, low stocking density ( 8 birds $/ \mathrm{m}^{2}$ ) and daily-cleaned bell drinkers. The environment with higher challenge was made up of re-used (after three broods of broilers) wood shavings as litter, high bird-density (16 birds $/ \mathrm{m}^{2}$ ) and bell drinkers cleaned every two days. The re-used litter suffered an anaerobic fermentation for 12 consecutive days right after the departure of the previous flock.

\section{EVALUATED CHARACTERISTICS}

Performance. The performance was evaluated at $42 \mathrm{~d}$ according to the following variables: feed intake, body weight gain, feed conversion ration (feed intake/body weight gain) and production viability [100 - mortality (\%)].

Intestinal morphometric parameters. Intestinal morphometric variables were evaluated by light microscopy, where a bird of each replication was sacrificed at $42 \mathrm{~d}$ of age after fasting for $12 \mathrm{~h}$. From each bird, a sample from the medial region of the duodenum was collected, opened and immediately fixed in Bouin solution for 24 hours. They were washed in $70 \%$ alcohol to remove the Bouin solution and were subsequently dehydrated in ascending series of alcohols, cleared in xylene and embedded in paraffin. Histological sections were made and stained according to the methodology of Giannenas et al (2010). Analyses were made by the program Image $J^{\circledR} 1$. The variables evaluated were height of the villi, villus width and crypt depth, being held 30 readings per intestinal region.

Carcass and commercial cuts yield. At $42 \mathrm{~d}$, two birds per replication with average weight were selected for determination of carcass yield. The birds were subjected to $12 \mathrm{~h}$ of fasting and killed by cervical dislocation. After bleeding by jugular vein, the birds were plucked and eviscerated. For carcass yield was considered the weight of clean and eviscerated carcass in relation to the live weight. For prime cuts, the calculation of yield was performed in relation to the weight of the eviscerated carcass.

Carcass chemical composition. To determine carcass chemical composition, two birds per group were slaughtered by cervical dislocation at $42 \mathrm{~d}$ after $12 \mathrm{~h}$ of fasting. After slaughter, carcasses were bled, plucked, eviscerated, frozen, crushed and dried in a forced circulation incubator at $55 \pm 2{ }^{\circ} \mathrm{C}$ for $72 \mathrm{~h}$. Then, the carcasses were analysed for content of dry matter, crude protein, ether extract, and mineral matter (Silva and Queiroz 2002).

\section{STATISTICAL ANALYSIS}

Data were analised using two-way ANOVA at 5\% of probability, using the Statistical Analysis System (SAS 2004) software. The statistical assumption of residual normality was evaluated using the Shapiro-Wilk while Levene's test was used for homogeneity of variances. The F test was used to compare the differences of main effects. The statistical model was:

$$
\mathrm{y}_{\mathrm{ijk}}=\mu+\mathrm{a}_{\mathrm{i}}+\mathrm{b}_{\mathrm{j}}+(\mathrm{a} \times \mathrm{b})_{\mathrm{ij}}+\mathrm{e}_{\mathrm{ijk}}
$$

Where: $y_{i j k}=$ response variable of broilers fed or not with probiotics $(i)$ and submitted or not to challenge $(j)$ in replication $\mathrm{k}$. $\mu=$ overall mean value for $y . a_{i}=$ fixed effect of probiotics. $b_{j}=$ fixed effect of challenge. $(a \times b)_{i j}=$ interaction among probiotics and challenge. $e_{i j k}=$ error term.

\section{RESULTS}

There was no significant interaction between the factors for any of the variables studied. No significant effect was observed with dietary supplementation of probiotics on

Rasband WS, Image J. 2004. National Institutes of Health. Bathesda,
Maryland, USA. Available at http://rsb.info.nih.gov/ij/ 
Table 1. Composition and calculated values of the experimental diets.

\begin{tabular}{|c|c|c|c|c|}
\hline \multirow{2}{*}{ Ingredients, \% } & \multicolumn{2}{|c|}{$\begin{array}{c}\text { Starter } \\
(1 \text { to } 21 \mathrm{~d})\end{array}$} & \multicolumn{2}{|c|}{$\begin{array}{c}\text { Finisher } \\
\text { (22 to } 42 \mathrm{~d})\end{array}$} \\
\hline & Control & Probiotics & Control & Probiotics \\
\hline Maize & 57.70 & 57.70 & 55.12 & 55.12 \\
\hline Soybean meal & 36.09 & 36.09 & 33.49 & 33.49 \\
\hline Soybean oil & 1.35 & 1.35 & 6.31 & 6.31 \\
\hline Dicalcium phosphate & 1.75 & 1.75 & 1.77 & 1.77 \\
\hline Limestone & 1.03 & 1.03 & 1.00 & 1.00 \\
\hline Sodium chloride & 0.49 & 0.49 & 0.52 & 0.52 \\
\hline DL-Methionine & 0.20 & 0.20 & 0.30 & 0.30 \\
\hline L-Lysine & 0.18 & 0.18 & 0.30 & 0.30 \\
\hline Probiotics ${ }^{1}$ & 0.00 & 1.00 & 0.00 & 1.00 \\
\hline Inert & 1.04 & 0.04 & 1.04 & 0.04 \\
\hline \multirow[t]{2}{*}{ Premix $^{2}$} & 0.12 & 0.12 & 0.10 & 0.10 \\
\hline & \multicolumn{4}{|c|}{ Composition } \\
\hline Metabolisable energy (kcal/kg) & 2,900 & 2,900 & 3,200 & 3,200 \\
\hline Crude protein $(\%)$ & 20.68 & 20.68 & 19.94 & 19.94 \\
\hline Calcium $(\%)$ & 0.93 & 0.93 & 0.90 & 0.90 \\
\hline Available P (\%) & 0.44 & 0.44 & 0.42 & 0.42 \\
\hline Sodium $(\%)$ & 0.21 & 0.21 & 0.20 & 0.20 \\
\hline Lysine $(\%)$ & 1.22 & 1.22 & 1.19 & 1.19 \\
\hline Methionine (\%) & 0.60 & 0.60 & 0.60 & 0.60 \\
\hline Methionine + cystine $(\%)$ & 0.90 & 0.90 & 0.91 & 0.91 \\
\hline
\end{tabular}

${ }^{1}$ Probiotics: Lactobacillus acidophilus $\left(1 \times 10^{9} \mathrm{ufc} / \mathrm{g}\right)$, Bacillus subtilis $\left(2,8 \times 10^{9} \mathrm{ufc} / \mathrm{g}\right)$, Bifidobacterium bifidum $\left(2 \times 10^{9} \mathrm{ufc} / \mathrm{g}\right)$ e Enterococcus faecium $\left(2 \times 10^{9} \mathrm{ufc} / \mathrm{g}\right)$.

${ }^{2}$ The vitamin premix supplied the following per kilogram of complete feed: vitamin A, 4,500 IU (retinyl acetate); cholecalciferol, 1,000 IU; vitamin E, $25 \mathrm{IU}$ (dl-a-tocopheryl acetate); vitamin B12, $0.02 \mathrm{mg}$; menadione, $1.5 \mathrm{mg}$; riboflavin, $3 \mathrm{mg}$; thiamine, $1.5 \mathrm{mg}$; pantothenic acid, $5 \mathrm{mg}$; niacin, $20 \mathrm{mg}$; choline, $150 \mathrm{mg}$; folic acid, $0.5 \mathrm{mg}$; biotin, $0.5 \mathrm{mg}$; pyridoxine, $2.5 \mathrm{mg}$; manganese $\left(\mathrm{MnSO}_{4} \cdot \mathrm{H}_{2} \mathrm{O}\right), 60 \mathrm{mg}$; zinc $\left.(\mathrm{ZnO}), 40 \mathrm{mg} ; \mathrm{iron}_{(\mathrm{FeSO}} \cdot 7 \mathrm{H}_{2} \mathrm{O}\right), 80$ $\mathrm{mg}$; copper $\left(\mathrm{CuSO}_{4} \cdot 5 \mathrm{H}_{2} \mathrm{O}\right), 8 \mathrm{mg}$; selenium $\left(\mathrm{Na}_{2} \mathrm{SeO}_{3}\right), 0.2 \mathrm{mg}$; iodine (Iodized $\left.\mathrm{NaCl}\right), 0.8 \mathrm{mg}$; cobalt $\left(\mathrm{CoCl}_{2}\right), 0.4 \mathrm{mg}$.

feed intake, weight gain, feed conversion and production viability (table 2). Animal raised on environment with higher challenge had reduced feed intake and weight gain compared to those raised under lower environmental challenge.

Birds fed diets with probiotics presented higher crypt depth compared to birds fed diets without probiotics (table 3). In addition, birds submitted to higher environmental challenge conditions showed higher crypt depth. The other morphometric variables had no significant effects.

The probiotics utilisation did not influence the carcass yield and commercial cuts (breast, drumstick + thigh, and wings) (table 4). However, the yield of drumstick + thigh was reduced when chickens were raised in environment with higher challenge. No significant effect was observed with probiotics or environment conditions on the chemical composition of the carcass (table 5).

\section{DISCUSSION}

In this study, the addition of probiotics into chicken's feed had no effect on the performance and carcass yield, contrary to previous studies that have showed improvements. Ramos et al (2014) reported increased feed intake and weight gain with the probiotics utilization (Lactobacillus acidophilus, Bifidobacterium bifidum and Streptococcus faecium), and attributed these results to the environment with re-used litter. Marubashi et al (2012) reported improved feed conversion in broilers fed diets supplemented with probiotic (Bacillus subtilis) compared to the control group.

Also, according to Sen et al (2012), probiotic based of Bacillus subtilis on different levels of inclusion in the diet increased weight gain and improved feed intake and feed conversion. On the other hand, other researchers have not verified the effect of probiotic supplementation on performance (Shargh et al 2012, Nosrati et al 2017) and on animal carcass traits (Souza et al 2011, Domingues et al 2014), attributing this effect to experimental environmental conditions.

Improvements in performance and carcass characteristics with the use of probiotics may occur due to increase in consumption and digestibility of the diet (Shim et al 2010). The probiotics could increase digestive enzymes 
Table 2. Performance ${ }^{1}$ of broiler chickens fed diets containing probiotics without or with challenge.

\begin{tabular}{|c|c|c|c|c|c|}
\hline \multirow{2}{*}{ Effects } & & \multicolumn{4}{|c|}{ Performance, 1 to $42 \mathrm{~d}$} \\
\hline & & Feed intake (g) & Weight gain $(\mathrm{g})$ & Feed:gain (g/g) & Viability (\%) \\
\hline \multirow[t]{2}{*}{ Probiotics } & - & 4,790 & 2,740 & 1.74 & 99.00 \\
\hline & + & 4,880 & 2,680 & 1.82 & 98.63 \\
\hline \multirow[t]{3}{*}{ Challenge } & - & 5,020 & 2,810 & 1.79 & 99.13 \\
\hline & + & 4,660 & 2,610 & 1.78 & 98.50 \\
\hline & $\mathrm{D}$ & 0.34 & 0.15 & 0.12 & 1.27 \\
\hline \multicolumn{2}{|c|}{ Source of variation } & \multicolumn{4}{|c|}{ Probability } \\
\hline \multicolumn{2}{|l|}{ Probiotics } & 0.6022 & 0.3373 & 0.2571 & 0.5646 \\
\hline \multicolumn{2}{|l|}{ Challenge } & 0.0422 & 0.0054 & 0.9169 & 0.3430 \\
\hline \multicolumn{2}{|c|}{ Probiotics $\times$ Challenge } & 0.8467 & 0.6666 & 0.6600 & 0.1921 \\
\hline
\end{tabular}

${ }^{1}$ Data represent means of 5 replicates $(n=15$ per replicate) in a treatment group.

Table 3. Duodenal morphometry* of broilers at $42 \mathrm{~d}$.

\begin{tabular}{|c|c|c|c|c|c|}
\hline \multirow{2}{*}{ Effects } & & \multicolumn{4}{|c|}{ Morphometry $(\mu \mathrm{m})$} \\
\hline & & Villus height & Crypt depth & Villus width & Villus:crypt \\
\hline \multirow[t]{2}{*}{ Probiotics } & - & 1,255 & 267.1 & 166.4 & 4.70 \\
\hline & + & 1,271 & 316.6 & 164.1 & 4.01 \\
\hline \multirow[t]{3}{*}{ Challenge } & - & 1,268 & 258.5 & 179.9 & 4.91 \\
\hline & + & 1,258 & 325.2 & 150.6 & 3.87 \\
\hline & & 140.93 & 61.85 & 58.05 & 1.23 \\
\hline \multicolumn{2}{|c|}{ Source of variation } & \multicolumn{4}{|c|}{ Probability } \\
\hline \multicolumn{2}{|l|}{ Probiotics } & 0.8467 & 0.0068 & 0.8768 & 0.1183 \\
\hline \multicolumn{2}{|l|}{ Challenge } & 0.8914 & 0.0009 & 0.0620 & 0.0971 \\
\hline \multicolumn{2}{|c|}{ Probiotics $\times$ Challenge } & 0.5675 & 0.5022 & 0.1316 & 0.7487 \\
\hline
\end{tabular}

*Data represent means of 5 replicates $(\mathrm{n}=1$ per replicate) in a treatment group.

Table 4. Slaughterhouse variables ${ }^{*}$ of broiler chickens at $42 \mathrm{~d}$.

\begin{tabular}{|c|c|c|c|c|c|}
\hline \multirow{2}{*}{ Effects } & & \multicolumn{4}{|c|}{ Yield (\%) } \\
\hline & & Carcass & Breast & Drumstick + Thigh & Wing \\
\hline \multirow[t]{2}{*}{ Probiotics } & - & 71.86 & 24.40 & 23.14 & 8.24 \\
\hline & + & 73.27 & 25.30 & 22.98 & 8.00 \\
\hline \multirow[t]{3}{*}{ Challenge } & - & 74.67 & 24.51 & 24.14 & 8.07 \\
\hline & + & 70.47 & 25.20 & 21.98 & 8.18 \\
\hline & & 4.58 & 3.29 & 2.19 & 0.78 \\
\hline \multicolumn{2}{|c|}{ Source of variation } & \multicolumn{4}{|c|}{ Probability } \\
\hline \multicolumn{2}{|c|}{ Probiotics } & 0.5348 & 0.5772 & 0.8574 & 0.5398 \\
\hline \multicolumn{2}{|c|}{ Challenge } & 0.0817 & 0.6725 & 0.0354 & 0.7892 \\
\hline \multicolumn{2}{|c|}{ Probiotics $\times$ Challenge } & 0.9404 & 0.0785 & 0.0706 & 0.1958 \\
\hline
\end{tabular}

*Data represent means of 5 replicates $(n=2$ per replicate) in a treatment group. 
Table 5. Carcass composition* of broilers at $42 \mathrm{~d}$.

\begin{tabular}{|c|c|c|c|c|c|}
\hline \multirow{2}{*}{ Effects } & & \multicolumn{4}{|c|}{ Carcass, $\%$} \\
\hline & & Dry matter & Crude protein & Ether extract & Ash \\
\hline \multirow[t]{2}{*}{ Probiotics } & - & 30.30 & 60.01 & 35.16 & 8.22 \\
\hline & + & 30.22 & 60.30 & 35.63 & 8.23 \\
\hline \multirow[t]{3}{*}{ Challenge } & - & 30.38 & 60.20 & 35.83 & 8.20 \\
\hline & + & 30.14 & 60.11 & 34.97 & 8.24 \\
\hline & & 0.21 & 4.42 & 2.13 & 0.83 \\
\hline \multicolumn{2}{|c|}{ Source of variation } & \multicolumn{4}{|c|}{ Probability } \\
\hline \multicolumn{2}{|l|}{ Probiotics } & 0.3205 & 0.8997 & 0.6909 & 0.9873 \\
\hline \multicolumn{2}{|l|}{ Challenge } & 0.4452 & 0.9677 & 0.4661 & 0.9327 \\
\hline \multicolumn{2}{|c|}{ Probiotics $\times$ Challenge } & 0.3307 & 0.2257 & 0.8126 & 0.8868 \\
\hline
\end{tabular}

*Data represent means of 5 replicates $(\mathrm{n}=2$ per replicate) in a treatment group.

activity (Jin et al 2000) and promote beneficial intestinal microbiota, improving intestinal health (Sen et al 2012).

The type of microorganism used in the probiotics can interfere with product efficiency. Bacillus subtilis is a spore resistant to heat and poor storage conditions, and it is considered safe to be used as probiotics (Fuller 1989). Another important point is the feed consumption, since most of the probiotics used in broilers demonstrates efficiency with daily intake of $10^{7}$ to $10^{9} \mathrm{cfu}$ (Patterson and Burkholder 2003, Mountzouris et al 2010). The dose used in the present test corresponded to the recommended range.

The action of probiotics is based on the mechanism of competitive exclusion, which depends on the oral administration of viable bacteria (Schneitz and Mead 2000). Perhaps, under the conditions of the present study the viability of the microorganisms may have been reduced, resulting in a reduced effect of probiotics.

In addition, the reduction on the feed consumption may have reduced the dose of probiotics that effectively reached the gastrointestinal tract, reducing prebiotics effectiveness. Other studies using different doses of compound probiotics reported variation in the responses of performance and carcass parameters, suggesting that the optimal concentration of probiotics in broiler feed varies with the microorganisms used in the composition of the product (Pourakbari et al 2016).

Regarding the environmental conditions used in this study, birds raised in an environment with higher challenge had lower feed intake, less weight gain and lower yield of drumstick + thigh, showing that environmental conditions used were detrimental to such variables. However, the results only show main effects of diet and environment, without interactions, suggesting that the higher density impacted the performance of birds but it was not enough to significantly change the probiotic effect. Forbes and Park (1959) suggested that the sanitary challenge must be sufficient to produce growth-promoting effects of additive utilisation in the animal performance.
Various researchers showed the negative effects of high animal density on the performance or broiler carcass (Dozier et al 2005, Dozier et al 2006, Jankowski et al 2014). However, regarding the re-used litter, there is disagreement between results. Some researchers have showed a negative effect of re-used litter on bird immunity (Lee et al 2011), and ammonia emissions in the environment (Malone 2006).

In contrast, using proper sanitary management, reused litter may present microbiological quality equal to or greater then new litter (Hess et al 2008, Muniz et al 2014), not resulting in increased environmental pollution (Chinivasagam et al 2010, Roll et al 2011). The reuse of litter in three previous flocks could not be enough to see detrimental effects. In addition, anaerobic fermentation of litter probably was effective in reducing the microbial load of the litter.

In this study, probiotics caused no effect on the villus height, on the villus width and on the relation villous:crypt. However, birds that have received diets with probiotics had lower crypt depth in the duodenum. Several studies show that the use of the Bacillus subtilis caused increased height of the intestinal villi (Sen et al 2012, Samanya and Yamauchi 2002) without changing the depth of the crypts. However, Mountzouris et al (2010) also did not found changes in height of the villi in the small intestine when using Lactobacillus reuteri, Enterococcus faecium, Bifidobacterium animalis, Pediococcus acidilactici and Lactobacillus salivarius combined, while no change occurred in the depth of the crypts.

Gunal et al (2006) found higher villus height in the jejunum and ileum of birds fed with combined probiotics (Lactobacillus acidophilus, Lactobacillus plantarum, Lactobacillus rhamnosus, Lactobacillus bulgaricus, Streptococcus thermophilus, Aspergillus orizea, Bifidobacterium bifidum, Enterococcus faecium, and Candida pintolepesii) and attributed this effect to the production of short-chain fatty acids by probiotics. The probiotics used in this study consists of Lactobacillus 
acidophilus, Bacillus subtilis, Bifidobacterium bifidum, and Enterococcus faecium. Microorganisms used as probiotics appear to cause different effects on the intestinal mucosa, suggesting that further investigations are needed on the action of different probiotics on the intestinal morphology of birds. Physiologically, cell renewal and proliferation are constant and occur as a result of mitotic divisions of stem cells located in the intestinal crypts (Uni et al 1998, Applegate et al 1999).

In the presence of some stimulus or invader, the intestine responds with imbalance in cell turnover (Maiorka et al 2002). The results of this experiment suggest a greater villi extrusion rate that may occur in birds raised in an environment with higher challenge. According to Furlan et al (2004), an increase in extrusion rate of the villi promotes cell proliferation in intestinal crypt epithelial, as an attempt to recover the loss of the apex of the villi and, as a result, there is an increase in the depth of intestinal crypts.

The present study demonstrated that yield of drumstick + thigh was reduced when chickens were raised in an environment with higher challenge, these results were expected, feed intake and weight gain were also affected by challenge, high density of birds impair litter quality, and negatively affect broiler performance (Garcia et al 2002, Oliveira et al 2004), consequently meat yield decreased.

The addition of probiotics in the diets did not affected chemical composition of the carcasses, similary Zhou et al (2010) observed no significant differences in the contents of moisture, ash, crude protein and ether extract.

However, Payard and Mahmoudi (2008) observed higher dry matter, crude protein and ether extract percentage in the carcasses using S. cerevisiae as probiotics, concluding that the effects on the characteristics of poultry carcasses are quite variable, demonstrating that specific studies for this point are still necessary.

In conclusion, the probiotics used do not influence the performance and the carcass characteristics, regardless of the environmental challenge, requiring further research using other types of challenges to investigate the effects of this additive in broiler production. The higher environment challenge decreased the feed intake, weight gain, drumstick + thigh yield and increased crypt depth of the broilers.

\section{REFERENCES}

Applegate TJ, Kitchell ML, Uni Z, Lilburn MS. 1999. Intestinal villus growth, enterocyte migration and proliferation of the turkey poultry. Comp Biochem Physi 124, 371-380.

Baracho MS, Cassiano JA, Nääs IA, Tonon GS, Garcia RG, et al. 2013. Ambiente interno em galpões de frango de corte com cama nova e reutilizada. Agrarian 6, 473-478.

Barton MD. 2000. Antibiotic use in animal feed and its impact on human health. Nutr Res Rev 13, 279-299.

Beloor J, Kang HK, Kim YJ, Subramani VK, Jang IS, et al. 2010. The effect of stocking density on stress related genes and telomeric length in broiler chickens. Asian-Austral J Anim 23, 437-443.

Boostani A, Mahmoodian Fard HR, Ashayerizadeh A, Aminafshar M. 2013. Growth performance, carcass yield and intestinal microflora populations of broilers fed diets containing thepax and yogurt. Rev Bras Cienc Avíc 15, 1-6.

Chinivasagam, HN, Redding M, Runge G, Blackall PJ. 2010. Presence and incidence of food-borne pathogens in Australian chicken litter. Brit Poultry Sci 51, 311-318.

Costa CAF, Guidoni AL, Paiva DP, Ávila VS. 2000. Coccidiosis and performance in broilers with anticoccidial medicated feed starting at different ages. Arq Bras Med Vet e Zoot 52, 144-149.

Cressman MD, Yu Z, Nelson MC, Moeller SJ, Lilburn MS, et al. 2010. Interrelations between the microbiotas in the litter and in the intestines of commercial broiler chickens. Appl Environ Microb 76, 6572-6582.

Domingues CH, Santos ET, Castiblanco DC, de Quadros TCO, Petrolli TG, et al. 2014. Avaliação do desempenho e rendimento de carcaça de frangos de corte alimentados com dietas contendo probiótico nas diferentes fases de criação. Rev Agrocientífica 1, 7-16.

Dozier WA, Thaxton JP, Branton SL, Morgan GW, Miles DM, et al. 2005. Stocking density effects on growth performance and processing yields of heavy broilers. Poult Sci 84, 1332-1338.

Dozier WA, Thaxton JP, Purswell JL, Olanrewaju HA, Branton SL, et al. 2006. Stocking density effects on male broilers grown to 1.8 kilograms of body weight. Poult Sci 85, 344-351.

Fallah R, Saghafi M, Rezaei H, Parvar R. 2013 Effect of Bioplus 2B ${ }^{\circledR}$ and Protoxin probiotics supplementation on growth performance, small intestinal morphology and carcass characteristics of broiler chickens Brit J Poult Sci 2, 11-15.

Forbes M, Park JT. 1959. Growth of germ-free and conventional chicks. Effect of diet, dietary penicillin and bacterial environment. $J$ Nutr 67, 69-84.

Fuller R. 1989. Probiotics in man and animals. J Appl Bact 66, 365-378.

Furlan LR, Macari M, Luquetti BC. 2004. Como avaliar os efeitos do uso de prebióticos, probióticos e flora de exclusão competitiva. In: Simpósio técnico de incubação, matrizes de corte e nutrição, Balneário Camboriú. Anais 6-28.

Garcia RG, Mendes AA, Garcia EA, Nääs IA, Moreira J, et al. 2002. Efeito da densidade de criação e do sexo sobre o empenamento, incidência de lesões na carcaça e qualidade da carne de peito de frangos de corte. Rev Bras Cienc Avíc 4, 1-9.

Giannenas I, Tontis D, Tsalie E, Chronis EF, Doukas D, et al. 2010. Influence of dietary mushroom agaricus bisporus on intestinal morphology and microflora composition in broiler chickens. Res Vet Sci 89, 78-84.

Guardia S, Konsak B, Combes S, Levenez F, Cauquil L, et al. 2011. Effects of stocking density on the growth performance and digestive microbiota of broiler chickens. Poult sci 90, 1878-1889.

Gunal M, Yayli G, Kaya O, Karahan N, Sulak O. 2006. The effects of antibiotic growth promoter, probiotic or organic acid supplementation on performance, intestinal microflora and tissue of broilers. Int $J$ Poult Sci 5, 149-155.

Hess JB, Macklin KS, Bilgili SF, Blake JP, Norton RA. 2008. In-house litter composting between flocks. In: Proceedings 2008 National Poultry Waste Management Symposium, October 21-23, Des Moines, Iowa, USA.

Huyghebaert G, Ducatelle R, Van Immerseel F. 2011. An update on alternatives to antimicrobial growth promoters for broilers. Vet $J$ 187, 182-188.

Jankowski J, Mikulski D, Tatara MR, Krupski W. 2014. Effects of increased stocking density and heat stress on growth, performance, carcase characteristics and skeletal properties in turkeys. Vet Rec, doi: 10.1136/vr.102216.

Jin LZ, Ho HW, Abdullah N, Jalaludin S. 2000. Digestive and bacteria enzyme activities in broilers fed diets supplemented with Lactobacillus cultures. Poul Sci 79, 886-891.

Lee KW, Lillehoj HS, Lee SH, Jang SI, Ritter GD, et al. 2011. Impact of fresh or used litter on the posthatch immune system of commercial broilers. Avian Dis 55, 539-544.

Malone B. 2006. Managing built-up litter. In: Proceedings to 2006 Midwest Poultry Federation Conference, St. Paul, MN, USA. 
Marubashi T, Gracia MI, Esteve-Garcia E, Piskoríková M. 2012. The efficacy of the probiotic feed additive Calsporin ${ }^{\circledR}$ (Bacillus subtilis C-3102) in broilers: combined analysis of four different studies. $J$ Appl Anim Nut 1, 878-901.

Maiorka A, Macari M. 2002. Absorção de minerais. In: Macari M, Furlan RL, Gonzales E (eds). Fisiologia aviária aplicada a frangos de corte. FUNEP/UNESP, Jaboticabal, Brazil.

Mendes AAA, Nääs IA, Macari M. 2004. Produção de frangos de corte. $1^{\mathrm{a}}$ ed. Facta, SP, Brazil.

Muniz E, Mesa D, Cuaspa R, Souza AM, Santin E. 2014. Presence of Salmonella spp. in reused broiler litter. Rev Colomb Cienc Pec 27, 12-27.

Mountzouris KC, Tsirtsikos P, Palamidi I, Arvaniti A, Mohnl M, et al. 2010. Effects of probiotic inclusion levels in broiler nutrition on growth performance, nutrient digestibility, plasma immunoglobulins, and caecal microflora composition. Poult Sci 89, 58-67.

Nosrati M, Javandel F, Camacho LM, Khusro A, Cipriano M, et al. 2017. The effects of antibiotic, probiotic, organic acid, vitamin $\mathrm{C}$, and Echinacea purpurea extract on performance, carcass characteristics, blood chemistry, microbiota, and immunity of broiler chickens. $J$ Appl Poult Res 26, 295-306.

Oliveira MC, Ferreira HA, Cancherini LC. 2004. Efeito de condicionadores químicos sobre a qualidade da cama de frango. Arq Bras Med Vet Zootec 56, 536-541.

Patel SG, Raval AP, Bhagwat SR, Sadrasaniya DA, Patel AP, et al. 2015. Effects of probiotics supplementation on growth performance, feed conversion ratio and economics of broilers. J Anim Res 5,155-160.

Patterson JA, Burkholder KM. 2003. Application of prebiotics and probiotics in poultry production. Poult Sci $82,627-631$.

Paryad A, Mahmoudi M. 2008. Effect of different levels of supplemental yeast (Saccharomyces cerevisiae) on performance, blood constituents and carcass characteristics of broiler chicks. African J Agri Res 3, 835-842.

Pourakbari M, Seidavi A, Asadpour L, Martínez A. 2016. Probiotic level effects on growth performance, carcass traits, blood parameters, cecal microbiota, and immune response of broilers. Anais da Academia Brasileira de Ciências 88, 1011-1021.

Puupponen-Pimiä R, Aura AM, Oksmancaldentey KM, Myllärinen P, Saarela M, et al. 2002. Development of functional ingredients for gut health. Trends Food Sci Tech, 13, 3-11.

Ramos LSN, Lopes JB, Ribeiro MN, Silva FES, Merval RR, et al. 2014. Aditivos alternativos a antibióticos para frangos de corte no período de 22 a 42 dias de idade. Rev Bras Saúde Prod Anim 15, 897-906.
Ravindran VDV, Thomas DG, Morel PCH. 2006. Performance and welfare of broilers as affected by stocking density and zinc bacitracin supplementation. J Anim Sci 77, 110-116.

Rostagno HS, Albino LFT, Donzele JL, Gomes PC, Oliveira RF, et al. 2005. Composição de alimentos e exigências nutricionais. Tabelas brasileiras para aves e suínos. $2^{\mathrm{a}} \mathrm{ed}$. Viçosa, MG, Brazil.

Roll VFB, Dai Pra MA, Roll AP.2011. Research on Salmonella in broiler litter reused for up to 14 consecutive flocks. Poult Sci 90, 2257-2262.

Samanya M, Yamauchi K. 2002. Histological alterations of intestinal villi in chickens fed dried Bacillus subtilis var. natto. Comp Biochem Physiol 133, 95-104.

SAS, Statistical Analysis System. 2004. SAS Version 9.1. SAS Institute Inc, Cary, NC, USA.

Schneitz C, Mead G. 2000. Competitive exclusion. In: Wray C, Wray A (eds). Salmonella in domestic animals. CAB International, Wallingford, UK.

Sen S, Ingale SL, Kim YW, Kim JS, Kim KH, et al. 2012. Effect of supplementation of Bacillus subtilis LS 1-2 to broiler diets on growth performance, nutrient retention, caecal microbiology and small intestinal morphology. Res Vet Sci 93, 264-268.

Shargh MS, Dastar B, Zerehdaran S, Khomeiri M, Moradi A. 2012. Effects of using plant extracts and a probiotic on performance, intestinal morphology, and microflora population in broilers. $J$ Appl Poult Res 21, 201-208.

Shim YH, Shinde PL, Choi JY, Kim JS, Seo DK, et al. 2010. Evaluation of multi-microbial probiotics produced by submerged liquid and solid substrate fermentation methods in broilers. Asian Austral $J$ Anim Sci 23, 521-529.

Silva DJ, Queiroz AC. 2002. Análise de alimentos: métodos químicos e biológicos. $3^{\mathrm{a}}$ ed. Editora UFV, Viçosa, MG, Brazil.

Souza LFAD, Araujo DN, Astolphi JLDL, Ambiel AC, Santos LS, et al. 2011. Probiótico e antibiótico como promotores de crescimento para frangos de corte. Colloq Agr 6, 33-39.

Timmerman HM, Veldman A, van den Elsen E, Rombouts FM, Beynen AC. 2006. Mortality and growth performance of broilers given drinking water supplemented with chicken-specific probiotics. Poult Sci 85, 1383-1388.

Uni Z, Ganot S, Sklan D. 1998. Posthatch development of mucosal function in the broiler small intestine. Poult Sci 77, 75-82.

Zhou X, Wang Y, Gu Q, Li W. 2010. Effect of dietary probiotic, Bacillus coagulans, on growth performance, chemical composition, and meat quality of Guangxi Yellow chicken. Poult Sci 89, 588-593. 
